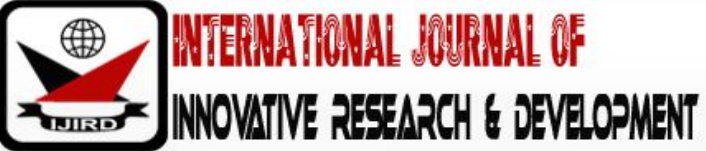

ISSN 2278 - 0211 (Online)

\section{Entrepreneurship Strategies in Achieving Aesthetic and Functional Products through Industrial Design Practices}

\author{
Mojirola Funmilayo Iheme \\ Principal Chief Technologist, Department of Industrial Design, Abubakar Tafawa Balewa University, Nigeria \\ Yohanna Ogbu Egiri \\ Lecturer, Department of Industrial Design, Abubakar Tafawa Balewa University, Nigeria \\ Isaac Ali Kwasu \\ Senior Lecture, Department of Industrial Design, Abubakar Tafawa Balewa University, Nigeria
}

\begin{abstract}
:
This paper discusses industrial design as a concept aimed at commodities created for appeal and function. It discusses who the industrial designer is and what he does, the strategies employed to achieve functional and aesthetic success for the endusers. The importance of form, function and marketing strategies in creating economically sustainable products were also explored and explained. The paper also stresses the importance of both aesthetics and function in the course of design and production of products. The forms of marketing techniques, strategies and services for such products were explained. Industrial design is described as a collaborative profession which requires working in harmony with other professionals to execute form and function. The paper is of the view that some industrial design practices bring art experiences to the public through the process of industrialisation. The industrial designers finish the creative endeavour and the object becomes a commodity that is appreciated, negotiated for and brings satisfaction to all concerned.
\end{abstract}

Keywords: Industrial design, function, aesthetics, entrepreneurship

\section{Introduction}

Every product in our homes, offices, or around us is created by designs. Industrial design firms are professional companies that create and develop concepts and specifications that optimize the function, value, and appearance of products and systems that relate most directly to human characteristics, needs, and interests (IDSA 2003, Bryson et al. 2004). Industrial design is the profession that bridges the gap between what is envisioned and what is possible. It is a Trans- disciplinary profession that harnesses creativity to resolve problems and co-create solutions with the intent of making a product, system, service, experience or a business better.

A design is a plan for arranging elements in such a way as best to accomplish a particular purpose (Eames, 2014). A good design should be appealing and functional (Fabian, 2009). A designer is adjudged successful when product design, development, management style, service delivery and performance efficiency are attained. An industrial designer derives satisfaction knowing that the products designed address a need and are patronised. The industrial designer desires to be sufficiently innovative, focused, passionate and committed to ensuring that finished products are not rejected or experience service failure. For each product design conceived, the designer adopts strategies uniquely suitable for consumers based on researched socio-economic cum cultural needs. The designer must be sufficiently committed to be innovative in removing apathy, boredom and rejection from end-users(Cooper, 2011). In all aspects, industrial design seamlessly blends form and function to make products truly desirable (May, 2014).

\subsection{The Industrial Design Profession}

It is a professional practice of designing products used by millions of people daily. Industrial designer does not only focus on the appearance of the product but also on how it is manufactured, its value, the experience it provides and ultimately how it is accepted.

Industrial design is the creation and development of concepts and specifications to optimise functions, value and aesthetics of products, structures and systems. It is the professional practice of designing products used by millions of people around the world every day.Ema(2012) opined that industrial design is a combination of various approaches in concept development, context analysis, contents validity, process management and product placement for efficient service delivery.

An industrial designer works within a collegial organisational and policy contexts on the institutional and societal setups that are supportive of the entrepreneurship and working industrial process. Industrial designers are part of a multidisciplinary team of strategists, engineers, user interface designers, user experience designers, project managers, branding experts, graphic designers manufacturers and customers all working together towards a common goal of an 
appropriate end product (Fish, 2014). Therefore they must accept and share responsibility for designs and be part of the marketing strategies to get the product out there to the end user. Since the primary aim of all designs is to improve the function, value and aesthetics of products; they must impact technical aspects of the overall design by considering the usability and aesthetics of design together. Designers must not only think of the physical appearance of the product, they need to understand the visual, safety and convenience needs of the consumers as well as the technical requirements and aesthetics.

\subsection{Collaboration and Communication in the Design Process}

The collaboration between a designer with many perspectives leads to a better understanding of a problem and crafting of products that meet aesthetic and functional uses.

Design and effective communication are partners in an effort to achieving aesthetic and functional products.Design principles, the set of guiding values that describe attributes of a given product type. Designers manage information, emotions and services. They also manage images consumers' desires and services. They plan, organize, guide and even lead their partners and clients through effective integration of the relevant elements of the design.

Manufacturing firms are increasingly employing design firms to assist in production. There is need for a close and trusting relationship to exist between the parties, absence of this can damage the survival of both firms and products. Trust has been viewed as beneficial to all parties involved, regardless of their exchange settings (Schurr and Ozanne 1985; Barney and Hansen 1994; Hosmer 1995; Das and Teng 1998; Sheppard and Sherman 1998). In other words, whether it is a business or personal encounter, trust positively helps shape and determine the existing and future relationship between or among the parties involved.

According to Industrial Design Society of America (IDSA,) one of the primary responsibilities of a design consultant is to create product specifications for goods that can be easily manufactured, look attractive, and work well. This means that designers typically operate across many spheres, including production-engineering, aesthetics (artistic creativity), ergonomics (Vanchan, 2007). The goal is to come up with a blueprint for an item that can be easily made with respect to client's specification. Design is a complex activity that involves innovation, change, invention, and creativity. These are the fundamental elements which contribute to the development of new products or the modification of existing products (Bryson et al. 2004).

\subsection{Basic Designing Process}

There are common processes and practices of industrial design.

- User research

- Sketching

- Comparative product research

- Model making

- Prototyping and modelling using computer aided designs(CAD)and

- Material selection

Ideas for designs need to be presented in colorful exciting and expressive ways. Powerful ideas generate appeal from the end-users. An industrial designer must be largely concerned with a variety of activities, which include orderliness, maintenance and distribution concerns.

\subsection{The Consumer}

The consumer is a critical factor in all the designer does. He is the focus of the whole design and production process. The fierce competition in the market place demands that customer needs and quirks be considered first. There is constant need to derive innovative ways to reach consumers. Newer and more technologically advanced tools are needed to keep products afloat in the marketplace and hold consumers' attention

Industrial designer designs products for various demography in all spheres of life, humans, pets, all races and gender. In order to achieve this, creativity and empathy are core attributes, the ability to walk in the clients' shoes. To do this, research is of utmost importance, it helps gain insight and informs the aesthetics and functionality of the design. Not by reflex alone. In transcending a design concept, a designer typically evokes the past, recognises the present and calls on the future (Cotanzia, 2010). It is of utmost importance that a research be done to determine who the consumer of a proposed design is. Research should also be done on similar products already in the market, prototyping or testing the product before final output.

Designers ought to relate to consumers in a very critical way. They apprehend the objective data of their reality through conscious reflections such as Demography and observing issues surrounding the end users.

\section{Entrepreneurship Strategies}

Entrepreneurship deals with the creation of economic growth system of activities and situations requiring the knowledge and understanding of economics, sociology, and human psychology and management skills. These are considered as very vital in any industrial design process and products. These, according to Dalton, (2007) are factors to consider as basic to all good design in the industrial process. 


\subsection{Research}

Research is very important like other variables in determining consumers' behaviour and their needs. After all, the products designers make are for them, hence it is expedient that we know their needs. People tend to develop brand loyalty and keep buying the same product over and over again (Mackenzie and Hardy, 1996). Therefore, it is important to carry out research on the end user to know where, when and how the product can be of benefit to them.

\subsection{Aesthetics}

A product must hold visual appeal and attraction. There is need to incorporate the elements of design; colour, harmony, form etc appropriately and still maintain functionality. Products should incorporate both the sensibility and sensuality (Ramirez, 2014).

\subsection{Creativity}

The fierce competition in the marketplace often demands that customer needs and quirks be considered often. There is need to constantly derive innovative ways to reach customers, identify opportunities to create value for your product within the identified demography.

\subsection{Marketing}

Knowing the usability of the product is one of the vital tool when it comes to marketing. How does it reflect on the corporate identity? How do you make the product appeal to the end user? Findings by a research on Taiwanese firms revealed that companies that use different marketing strategies employ different innovation strategies in product design, (Hsu, 2013).

\subsection{Technology}

There is need to periodically update aspects of a product, either its packaging, form or marketing strategy to match up with technological advancements. Newer and more technically advanced tools are used to hold customer attention. An example is using call centres to get customers in a seeming one-on-one meeting. (Prabhaker, Sheehan and Coppett, 1997). Cable companies, banks and telecom service providers make use of this a lot in Nigeria

\subsection{Evaluate}

Evaluate product safety, appearance and function to see if it's practical, evaluate the usability of products, how user friendly it is. The safety consciousness is part of the strategy to adopt

\section{Conclusion}

Professional practice is a full time occupational calling in an organised work setting in which one is proficient in earning a living. Therefore, the industrial designers ought to be properly schooled in producing marketable products that serve form and function through the use of entrepreneurship strategic practices.

\section{References}

i. Beyers, W. and Lindahl, D. (1996) Explaining the Demand for Producer Services: Is Cost-Driven Externalization the Major Factor? Paper in Regional Science 75: 351-374.

ii. Bryson, J. and Daniels, P and Rusten, G. (2005) Inside the 'Industrial' Design World: Understanding The Relationship Between Industrial Design Expertise, Product development, and the manufacturing process. (Presented at the 2005 Annual Association of American Geographers Meeting, Denver, Colorado)

iii. Costanzia, H. (2010) Planning, Producing and Using Industrial Designs. Journal of creative arts, 32(1) 56-62

iv. Cooper, G.and Locke, E. (2014) Industrial and Organizational Psychology www.akademika.com, retrieved 2018.

v. Cooper, W. (2011) Fundamentals of Industrial Processes. Freetown Morgan Press.

vi. Dalton, H. (2007) Introduction to Entrepreneurship. SRL seminal series

vii. Das, T. and Teng, B. (1998) Between Trust and Control: Developing Confidence in Partner Cooperation in Alliances. The Academy of Management Review 23 (3): 491-512.

viii. Ema, E. (2012), Basic Issues and Methodology in Industrial Design, Calabar University Press

ix. Fabian, O. (2009) Branding, the Power of Design. Kwesi Quansat Publications, Accra

x. Fish, L. (2017), the Core Elements of Product Design: Strategies, Pillars and Principles. www.researchin flanders.be

xi. Hosmer, L. (1995) Trust: The Connecting Link between Organizational Theory and Philosophical Ethics. The Academy of Management Review 20 (2): 379-403.

xii. Hsu Y. (2011), design innovation and marketing strategy in successful product completion. Journal of Business and Industrial Marketing, vol. 26 issue 4, pp203-236

xiii. Mackenzie, H. and Hardy, K. (1996), Manage Your Offering or Manage Your Relationship?

xiv. Probhaker, P. Sheehan, Mand Coppett,J.(1997), The Power of Technology in Business Selling; Call Centres. Journal of business and industrial Marketing, vol 12 issue 314. Pp222-235

xv. Ramirez R. (2011), Elements Of Surprise; Industrial Designers Strategies For Eliciting Surprise Through Interaction. www.businessdictionaries.com retrieved 2018

xvi. Ramirez, R. (2014): Industrial Design Strategies For Eliciting surprise. www.science.com retrieved April, 2018 
xvii. Schurr, P. and Ozanne, J. (1985) Influences on Exchange Processes: Byers' Preconceptions of a Seller's Trustworthiness and Bargaining Toughness. The Journal of Consumer Research 11 (4): 939-953.

xviii. Sheppard, B. and Sherman, D. (1998), The Grammars of Trust: A Model and General Implications. The Academy of Management Review, 23 (3): 422-437.

xix. Tom, M. (2014), Who is an Industrial Designer? www.creative blog.com

xx. Vanchan V. (2007) Communication and Relationships between Industrial Design Companies and their CustomersThe Industrial Geographer, Volume 4,issue 2, p. 28-46 2007 